\title{
A Solitary Intestinal Myofibroma: A Rare Cause of Neonatal Anemia
}

\author{
Janna S.E. Ottenhoff ${ }^{a}$ Peter G.J. Nikkels ${ }^{b}$ \\ C.E.J. Terwisscha van Scheltinga ${ }^{c} \quad$ L. Naeije $^{d}$ \\ a Department of Pediatrics, Wilhelmina Children's Hospital, University Medical Center \\ Utrecht, Utrecht, The Netherlands; ${ }^{b}$ Department of Pathology, University Medical Center

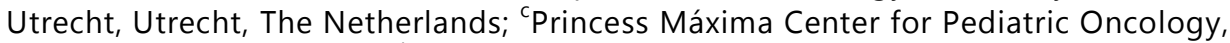 \\ Utrecht, The Netherlands; ${ }^{d}$ Department of Pediatric Oncology, Hematology and BMT, \\ BC Children's Hospital, Vancouver, BC, Canada
}

\section{Keywords}

Myofibroma · Gastrointestinal surgery · Neonatal anemia - Intestinal obstruction

\section{Abstract}

Solitary infantile myofibroma with visceral involvement is very rare. We present an unusual case of a solitary myofibroma with abdominal localization in a 1-day-old female neonate who presented with severe anemia and rectal bleeding. A bleeding myofibroma was found, located in the wall of the jejunum, and totally resected. In case of a solitary lesion, treatment is relatively easy and effective, with excellent prognosis after total resection. The multiple form (myofibromatosis) has a poor prognosis with low survival rates. We therefore recommend total body MRI for all patients diagnosed with myofibroma to rule out other lesions. 


\section{Case Reports in Oncology}

Case Rep Oncol 2017;10:890-896

DOI: $10.1159 / 000481305$

(C)

(C) 2017 The Author(s). Published by S. Karger AG, Basel www.karger.com/cro

Ottenhoff et al.: A Solitary Intestinal Myofibroma: A Rare Cause of Neonatal Anemia

\section{Introduction}

A female neonate, born at term, presented with paleness, single rectal bleeding, and severe anemia (Hb $10.6 \mathrm{~g} / \mathrm{dL}$, MCV $110 \mathrm{fL}$ ) on day 1 after birth. Besides pallor, pediatric examination revealed no other abnormalities. An erythrocyte transfusion was given and Hb levels increased to $14.7 \mathrm{~g} / \mathrm{dL}$. However, Hb levels declined rapidly to $11.0 \mathrm{~g} / \mathrm{dL}$ within 6 days. Perinatal infection was considered as potential cause for the anemia, and intravenous antibiotics were given for 7 days. Diagnostic anemia workup was initiated but revealed no hematological laboratory abnormalities. Abdominal ultrasound revealed a solid mass measuring $6.2 \times$ $5.2 \times 2.5 \mathrm{~cm}$ on the right side of the abdomen (Fig. 1). On the following ultrasound though, the mass was located on the left side of the abdomen. Due to the apparent mobility of the lesion, a solid tumor arising from the ovaries was considered. Other differential diagnostic possibilities considered were an intestinal duplication cyst; immature teratoma; germ cell tumor; and neuroblastoma stadium 4S. The subsequent MRI was not sufficient due to the movement of the patient. On an exploratory laparoscopy, no abnormalities of the ovaries were seen. Laparoscopy was therefore converted to laparotomy for further inspection.

During the laparotomy, a solid, easily bleeding mass on the mesenterial side of the jejunum was found. Resection of the 4-cm jejunum - including the lesion - and end-to-end anastomosis were performed. Pathological examination of the resected specimen showed a solid spindle cell lesion within the intestinal wall with superficial ulceration and infiltrative borders in the muscle layers of the intestinal wall and in the mesentery (Fig. 2a, b). The cells were arranged in small irregular bundles with ovoid shape and nuclei without atypia. There were irregular vessels with a hemangiopericytoma like appearance. There was some necrosis and hemorrhage within the tumor. Calcification or hyalinization was not present. Immunohistochemical analysis revealed positive staining for vimentin, alpha-SMA, and CD34 and a negative staining for calretinin, caldesmon, and desmin (Fig. 2c, d). The histology and immunohistological markers were characteristic of infantile myofibroma. The postoperative course was uneventful and the patient recovered well with normal and stable Hb levels. A total body MRI was made postoperatively to rule out multiple lesions. Further follow-up was performed through abdominal ultrasound. No recurrence of the lesion and no other lesions were seen, confirming the diagnosis of an infantile solitary abdominal myofibroma.

\section{Discussion}

In this neonatal case, we report a solitary abdominal myofibroma as the cause of neonatal anemia. Although infantile myofibroma is rare, it is one of the most common fibrotic tumors in children, first described in 1951 [1]. A solitary lesion in the abdomen though is very rare. A literature search revealed only 20 other reported cases of a solitary infantile abdominal myofibroma (Table 1); however, it is the first case in which anemia is the primary presentation of the underlying disease [2-18]. The typical presentation of an intestinal myofibroma is associated with bowel perforation or obstruction, accompanied by obstructive symptoms such as vomiting and abdominal distention [18]. Infantile myofibromas are classified into two forms: the single and the multiple form. The multiple form - also known as myofibromatosis with or without visceral involvement - is more common in girls and can 


\section{Case Reports in Oncology}

present in a great variety of symptoms, depending on location, such as subcutaneous muscular or bones. Visceral involvement is seen in 30\%. In contrast to solitary lesions, the prognosis of the multiple form is poor, with mortality rates up to $76 \%$, mostly caused by cardiopulmonary or gastrointestinal complications [19]. New findings show that there might be a genetic component in the familiar form of infantile myofibromatosis due to mutations in the PDGFRB gene [20, 21]. In contrast to the multiple form, the single form presents most often with a lesion of the subcutis. Visceral involvement is rare and found in less than $4 \%$ of the solitary lesions [1]. The prognosis of this form is excellent when totally resected. No recurrence or metastasis has been reported $[15,18]$.

\section{Conclusion}

An intestinal myofibroma can be the cause of unexplained neonatal anemia and should therefore be considered in the differential diagnosis. Treatment is surgical and the prognosis is excellent. The existence of additional lesions which complicate prognosis and treatment should be ruled out by a total body MRI.

\section{Statement of Ethics}

Informed consent for publication was obtained from the parents of the participant. For this type of study formal consent is not required because this is a case report.

\section{Disclosure Statement}

The authors declare that they have no conflicts of interest.

\section{Funding Sources}

There is no funding to report for this paper.

\section{References}

1 Schurr P, Moulsdale W: Infantile myofibroma: a case report and review of the literature. Adv Neonatal Care 2008;8:13-20.

2 Numanoglu A, Davies J, Millar AJ, Rode H: Congenital solitary intestinal fibromatosis. Eur J Pediatr Surg 2002;12:337-340.

- Kauffman SL, Stout AP: Congenital mesenchymal tumours. Cancer 1965;18:460-476.

4 Walts AE, et al: Solitary lesion of congenital fibromatosis: a rare cause of neonatal intestinal obstruction. Am J Surg Pathol 1982;6:255-260.

5 Srigley JR, Mancer K: Solitary intestinal fibromatosis with perinatal bowel obstruction. Pediatr Pathol 1984;2:249-258. 
Gonzales-Crussi F, Noronha R: Solitary intestinal fibromatosis in the newborn. Arch Pathol Lab Med 1985;109:97-100. 1989;9:719-724.

Saguem MH, et al: La forme intestinale isolée des myofibromatosis infantiles. Ann Pathol 1990;10:126129.

Chang WL, Griffith KM: Solitary intestinal fibromatosis: a rare cause of intestinal obstruction in neonate and infant. J Pediatr Surg 1991;26:1406-1408.

Vazquez Rueda F, et al: Fibromatosis intestinal solitaria: una causa rara de obstruction intestinal neonatal. Cir Pediatr 1993;6:95-97.

Türken A, et al: Solitary intestinal fibromatosis mimicking malabsorption syndromes. J Pediatr Surg 1995;30:1387-1389.

Al-Salem AH, Al-Hayek R, Qureshi SS: Solitary intestinal fibromatosis: a rare cause of intestinal perforation in neonates. Pediatr Surg Int 1997;12:437-440.

Lacson AG, et al: Pathological case of the month. Arch Pediatr Adolesc 2000;154:203-204.

Arets HGM, Borzi PA, Mortimore RJ: Solitary intestinal fibromatosis as a cause of bile vomiting in a neonate. J Pediatr Surg 2000;35:643-645.

Choo KL, Borzi PA, Mortimore RJ: Neonatal intestinal obstruction from solitary intestinal fibromatosis. Pediatr Surg Int 2001;17:467-469.

Menéndez-Arzac R, Valdez-Méndez D, Landa R, Guzmán S, Cárdenas E, Cano AM: Solitary infantile gastrointestinal myofibroma: case report. J Pediatr Surg 2005;40:1361-1363.

Coulon A, McHeik J, Milin S, Levard G, Levillain P, Fromont G: Solitary intestinal fibromatosis associated with congenital ileal atresia. J Pediatr Surg 2007;42:1942-1945.

Eid HA, Abusrair H, Almowasher F, Nasrhullah R, Alkhater M, Almarhoon Z: Solitary intestinal myofibroma - an unusual cause of neonatal intestinal obstruction. Ann Saudi Med 2014;34:544-547. Wiswell TE, Sakas EL, Stephenson SR, Lesica JJ, Reddoch SR: Infantile myofibromatosis. Pediatrics 1985;76:981-984.

Cheung YH, Gayden T, Campeau PM, LeDuc CA, Russo D, Nguyen VH, et al: A recurrent PDGFRB mutation causes familial infantile myofibromatosis. Am J Hum Genet 2013;92:996-1000.

Agaimy A, Bieg M, Michal M, Geddert H, Märkl B, Seitz J, et al: Recurrent somatic PDGFRB mutations in sporadic Infantile/solitary adult myofibromas but not in angioleiomyomas and myopericytomas. Am J Surg Pathol 2017;41:195-203. 


\section{Case Reports in Oncology}

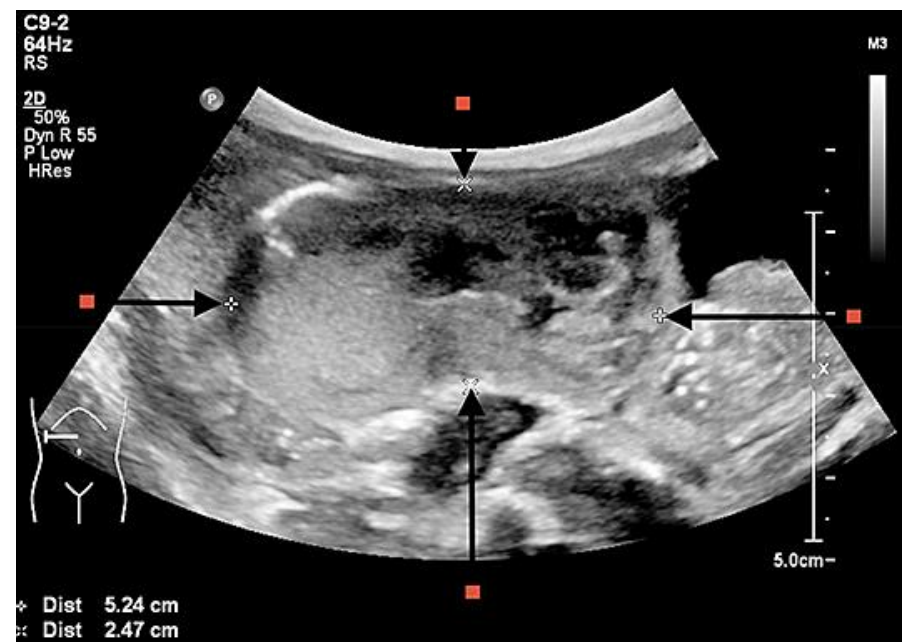

Fig. 1. A solid inhomogeneous mass on the right side of the abdomen, measuring $6.2 \times 5.2 \times 2.5 \mathrm{~cm}$ (CC $\times$ LR $\times$ AP). 


\section{Case Reports in Oncology}
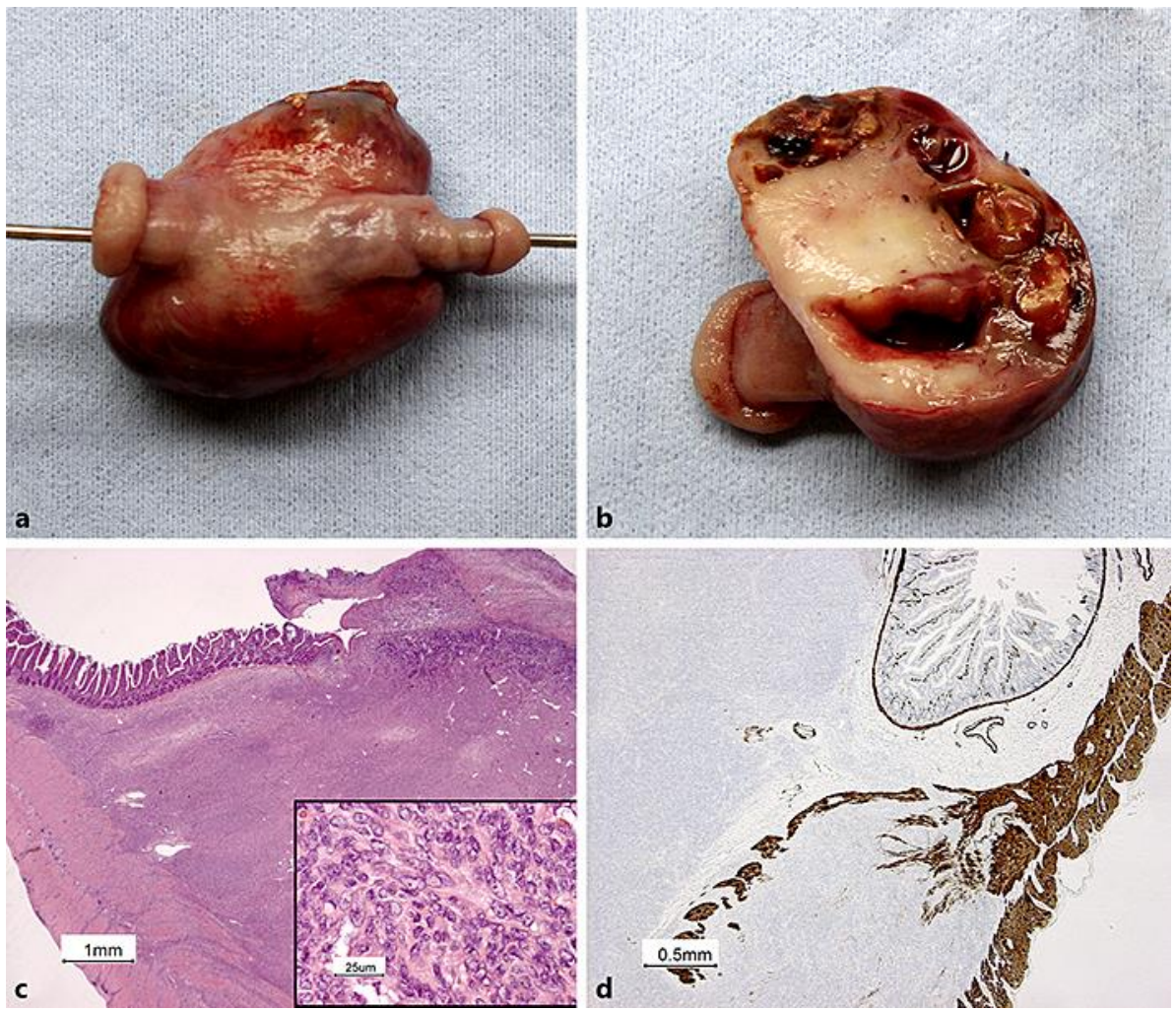

Fig. 2. a Macroscopical picture of the resection specimen with a probe in the lumen of the 6-cm long resected fragment of the small intestine. The tumorous mass $(5 \times 4 \times 3 \mathrm{~cm})$ is oriented on the mesenteric side of the specimen and on cut surface (b) and shows a partly solid white and partly hemorrhagic cystic appearance. c Histological aspect with focal ulceration of the intestinal mucosa and infiltration of the tunica muscularis. HE stain. Inset Higher power of the cells of the lesion with ovoid nuclei with small nucleoli and some eosinophil cytoplasm. HE stain. $\mathbf{d}$ Immunohistological stain with caldesmon, highlighting the infiltrative pattern of the negative tumor cells in the smooth muscle layer of the muscularis propria. 
Table 1. Overview of congenital solitary intestinal myofibromas

\begin{tabular}{|c|c|c|c|c|c|c|c|c|}
\hline Year & Authors [Ref.] & Age & Sex & Clinical presentation & Location & Operation & Follow-up & Outcome \\
\hline 1965 & $\begin{array}{l}\text { Kauffman and } \\
\text { Stout [3] }\end{array}$ & Neonate & M & $\begin{array}{l}\text { Intestinal } \\
\text { obstruction }\end{array}$ & Jejunum & $\begin{array}{l}\text { Resection, } \\
\text { anastomosis }\end{array}$ & 9 months & Good \\
\hline 1965 & $\begin{array}{l}\text { Kauffman and } \\
\text { Stout [3] }\end{array}$ & Neonate & M & $\begin{array}{l}\text { Intestinal } \\
\text { obstruction }\end{array}$ & Jejunum & $\begin{array}{l}\text { Resection, } \\
\text { anastomosis }\end{array}$ & 5 years & Good \\
\hline 1982 & Walts et al. [4] & 2 days & M & $\begin{array}{l}\text { Intestinal } \\
\text { obstruction }\end{array}$ & Ileum & $\begin{array}{l}\text { Resection, } \\
\text { anastomosis }\end{array}$ & 18 months & Good \\
\hline 1984 & $\begin{array}{l}\text { Srigley and } \\
\text { Mancer [5] }\end{array}$ & 2 days & M & $\begin{array}{l}\text { Obstruction, } \\
\text { prenatal perforation }\end{array}$ & $\begin{array}{l}\text { Transverse } \\
\text { colon }\end{array}$ & $\begin{array}{l}\text { Resection, } \\
\text { colostomy }\end{array}$ & 10 years & Good \\
\hline 1984 & $\begin{array}{l}\text { Srigley and } \\
\text { Mancer [5] }\end{array}$ & 2 days & M & $\begin{array}{l}\text { Obstruction, } \\
\text { prenatal perforation }\end{array}$ & Ileum & $\begin{array}{l}\text { Resection, } \\
\text { anastomosis }\end{array}$ & 5 years & Good \\
\hline 1984 & $\begin{array}{l}\text { Srigley and } \\
\text { Mancer [5] }\end{array}$ & 1 day & M & $\begin{array}{l}\text { Intestinal } \\
\text { obstruction }\end{array}$ & Jejunum & $\begin{array}{l}\text { Resection, } \\
\text { anastomosis }\end{array}$ & 26 months & Good \\
\hline 1985 & $\begin{array}{l}\text { Gonzales-Crussi } \\
\text { and Noronha [6] }\end{array}$ & 4 months & $\mathrm{F}$ & $\begin{array}{l}\text { GI bleeding and } \\
\text { obstruction }\end{array}$ & $\begin{array}{l}\text { Mid small } \\
\text { bowel }\end{array}$ & $\begin{array}{l}\text { Resection } \\
\text { anastomosis }\end{array}$ & 9 years & Good \\
\hline 1989 & $\begin{array}{l}\text { Canioni et al. } \\
\text { [7] }\end{array}$ & 6 years & M & $\begin{array}{l}\text { Pyloric } \\
\text { obstruction }\end{array}$ & $\begin{array}{l}\text { Pyloroduodenal } \\
\text { junction }\end{array}$ & $\begin{array}{l}\text { Resection } \\
\text { anastomosis }\end{array}$ & 2 years & Good \\
\hline 1990 & $\begin{array}{l}\text { Saguem et al. } \\
\text { [8] }\end{array}$ & 1 day & $\mathrm{F}$ & $\begin{array}{l}\text { Intestinal } \\
\text { obstruction }\end{array}$ & Jejunum & $\begin{array}{l}\text { Resection } \\
\text { anastomosis }\end{array}$ & 25 months & Good \\
\hline 1991 & $\begin{array}{l}\text { Chang and } \\
\text { Griffith [9] }\end{array}$ & 5 months & $\mathrm{M}$ & $\begin{array}{l}\text { Intestinal } \\
\text { obstruction }\end{array}$ & Ileum & $\begin{array}{l}\text { Resection, } \\
\text { anastomosis }\end{array}$ & 5 years & Good \\
\hline 1993 & $\begin{array}{l}\text { Vazquez Rueda } \\
\text { et al. [10] }\end{array}$ & 1 day & $?$ & $\begin{array}{l}\text { Intestinal } \\
\text { obstruction }\end{array}$ & Jejunum & $\begin{array}{l}\text { Resection, } \\
\text { anastomosis }\end{array}$ & & Good \\
\hline 1995 & $\begin{array}{l}\text { Türken et al. } \\
\text { [11] }\end{array}$ & 17 months & $\mathrm{F}$ & $\begin{array}{l}\text { Hematemesis, } \\
\text { malabsorption, obstruction }\end{array}$ & Jejunum & $\begin{array}{l}\text { Resection, } \\
\text { anastomosis }\end{array}$ & 2 years & Good \\
\hline 1997 & $\begin{array}{l}\text { Al-Salem } \\
\text { et al. [12] }\end{array}$ & 4 days & $\mathrm{F}$ & $\begin{array}{l}\text { Intestinal } \\
\text { perforation }\end{array}$ & $\begin{array}{l}\text { Descending } \\
\text { colon }\end{array}$ & $\begin{array}{l}\text { Resection, } \\
\text { colostomy }\end{array}$ & 8 months & Good \\
\hline 2000 & $\begin{array}{l}\text { Lacson et al. } \\
{[13]}\end{array}$ & 5 months & M & $\begin{array}{l}\text { Intestinal } \\
\text { obstruction }\end{array}$ & $\begin{array}{l}\text { Splenic flexure } \\
\text { colon }\end{array}$ & $\begin{array}{l}\text { Resection, } \\
\text { anastomosis }\end{array}$ & 6 months & Good \\
\hline 2000 & Arets et al. [14] & 3 days & $\mathrm{M}$ & $\begin{array}{l}\text { Intestinal } \\
\text { obstruction }\end{array}$ & $\begin{array}{l}\text { Mid small } \\
\text { bowel }\end{array}$ & $\begin{array}{l}\text { Resection, } \\
\text { anastomosis }\end{array}$ & 3 years & Good \\
\hline 2001 & Choo et al. [15] & 4 days & M & $\begin{array}{l}\text { Intestinal } \\
\text { obstruction }\end{array}$ & Jejunum & $\begin{array}{l}\text { Resection, } \\
\text { anastomosis }\end{array}$ & 9 months & Good \\
\hline 2001 & $\begin{array}{l}\text { Numanoglu } \\
\text { et al. [2] }\end{array}$ & 6 days & M & $\begin{array}{l}\text { Intestinal } \\
\text { obstruction }\end{array}$ & $\begin{array}{l}\text { Transverse } \\
\text { colon }\end{array}$ & $\begin{array}{l}\text { Resection, } \\
\text { colostomy }\end{array}$ & 12 months & Good \\
\hline 2005 & $\begin{array}{l}\text { Menéndez- } \\
\text { Arzac et al. [16] }\end{array}$ & 7 years & $\mathrm{F}$ & $\begin{array}{l}\text { Intestinal } \\
\text { obstruction }\end{array}$ & Ileum & $\begin{array}{l}\text { Resection, } \\
\text { anastomosis }\end{array}$ & & Good \\
\hline 2007 & $\begin{array}{l}\text { Coulon et al. } \\
{[17]}\end{array}$ & 1 day & $\mathrm{F}$ & $\begin{array}{l}\text { Intestinal } \\
\text { obstruction }\end{array}$ & $\begin{array}{l}\text { Ileum } \\
\text { (atresia) }^{1}\end{array}$ & $\begin{array}{l}\text { Resection, } \\
\text { anastomosis }\end{array}$ & 28 months & Good \\
\hline 2014 & Eid et al. [18] & 17 days & $\mathrm{F}$ & $\begin{array}{l}\text { Intestinal } \\
\text { obstruction }\end{array}$ & Ileum & $\begin{array}{l}\text { Resection, } \\
\text { anastomosis }\end{array}$ & & Good \\
\hline 2016 & Present case & 1 day & $\mathrm{F}$ & $\begin{array}{l}\text { Anemia, rectal } \\
\text { blood loss }\end{array}$ & Jejunum & $\begin{array}{l}\text { Resection, } \\
\text { anastomosis }\end{array}$ & 6 months & Good \\
\hline
\end{tabular}

GI, gastrointestinal. ${ }^{1}$ Strong suspicion of spontaneous recurrence of a myofibroma, which caused the atresia. 